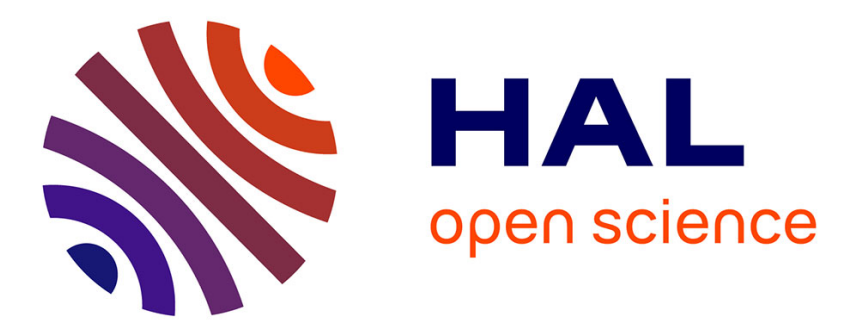

\title{
Decomposition of CoF3 during Battery Electrode Processing
}

\author{
Wei Li, Henri Groult, Olaf Borkiewicz, Damien Dambournet
}

\section{To cite this version:}

Wei Li, Henri Groult, Olaf Borkiewicz, Damien Dambournet. Decomposition of CoF3 during Battery Electrode Processing. Journal of Fluorine Chemistry, 2017. hal-01656914

\section{HAL Id: hal-01656914 https://hal.sorbonne-universite.fr/hal-01656914}

Submitted on 6 Dec 2017

HAL is a multi-disciplinary open access archive for the deposit and dissemination of scientific research documents, whether they are published or not. The documents may come from teaching and research institutions in France or abroad, or from public or private research centers.
L'archive ouverte pluridisciplinaire HAL, est destinée au dépôt et à la diffusion de documents scientifiques de niveau recherche, publiés ou non, émanant des établissements d'enseignement et de recherche français ou étrangers, des laboratoires publics ou privés. 
[Title Page]

\title{
Decomposition of $\mathrm{CoF}_{3}$ during Battery Electrode
}

\section{Processing}

\author{
Wei Li ${ }^{\mathrm{a}}$, Henri Groult ${ }^{\mathrm{a}}$, Olaf J. Borkiewicz ${ }^{\mathrm{b}}$, Damien Dambournet ${ }^{\mathrm{a}, \mathrm{c}, *}$ \\ a Sorbonne Universités, UPMC Univ Paris 06, CNRS UMR 8234, Laboratoire PHENIX, \\ 4 place Jussieu, F-75005 Paris, France \\ ${ }^{\mathrm{b}}$ X-ray Science Division, Advanced Photon Source, Argonne National Laboratory, \\ 9700 South Cass Avenue, Argonne, Illinois 60439, United States \\ ${ }^{\mathrm{c}}$ Réseau sur le Stockage Electrochimique de 1'Energie (RS2E), FR CNRS 3459, 80039 \\ Amiens, France \\ Correspondence information: Damien Dambournet, damien.dambournet@upmc.fr
}




\title{
Decomposition of $\mathrm{CoF}_{3}$ during Electrode Processing
}

\author{
Wei Li ${ }^{\mathrm{a}}$, Henri Groult ${ }^{\mathrm{a}}$, Olaf J. Borkiewicz ${ }^{\mathrm{b}}$, Damien Dambournet ${ }^{\mathrm{a}, \mathrm{c}, *}$ \\ a Sorbonne Universités, UPMC Univ Paris 06, CNRS UMR 8234, Laboratoire PHENIX, \\ 4 place Jussieu, F-75005 Paris, France \\ ${ }^{\mathrm{b}}$ X-ray Science Division, Advanced Photon Source, Argonne National Laboratory, \\ 9700 South Cass Avenue, Argonne, Illinois 60439, United States \\ ${ }^{\text {c }}$ Réseau sur le Stockage Electrochimique de l'Energie (RS2E), FR CNRS 3459, 80039 \\ Amiens, France
}

\begin{abstract}
Metal fluorides are potential candidates as electrode materials for rechargeable batteries. During the electrode fabrication, however, thermal treatments can cause decomposition of thermally instable compounds. Here, we showed that during the electrode processing of $\mathrm{CoF}_{3}$, the carbon and PVDF additives act as a protective layer that prevents $\mathrm{CoF}_{3}$ to readily decompose into $\mathrm{CoF}_{2}$ (rutile). We found that instead, it decomposes into an intermediate phase with a corundum like structure featuring Co vacancies, i.e., $\mathrm{Co}_{1.26}{ }^{\mathrm{II}} \mathrm{Co}_{0.16}{ }^{\mathrm{III}} \square_{0.58} \mathrm{~F}_{3}$ where $\square$ represents the vacancies. The structural analysis was possible owing to the use of the pair distribution function.
\end{abstract}

PACS(optional, as per journal): 75.40.-s; 71.20.LP

Keywords: Corundum, rutile, $\mathrm{ReO} 3$, pair distribution function, Li-ion batteries 


\section{Introduction}

Since the pioneer work of Poizot et $a l,[1]$ on the use of binary transition metal oxide as conversion materials for lithium-ion batteries, a large number of compounds have been reported to undergo such a multi-electronic redox reaction.[2] Particularly, extended studies have been related to the use of transition metal fluorides including $\mathrm{FeF}_{3}, \mathrm{TiF}_{3}, \mathrm{VF}_{3}$ and $\mathrm{CoF}_{3} .[3-6]$

High valence metal fluorides such as $\mathrm{CoF}_{3}$ can decompose into binary fluoride with the release of molecular fluorine gas which make them potential solid fluorinating agent.[7] The thermal decomposition path of $\mathrm{CoF}_{3}$, however, largely depends on the operating conditions.[8] Traces of humidity can promote the decomposition of $\mathrm{CoF}_{3}$ according to:

$2 \mathrm{CoF}_{3}+\mathrm{H}_{2} \mathrm{O} \rightarrow 2 \mathrm{CoF}_{2}+2 \mathrm{HF}+1 / 2 \mathrm{O}_{2}($ eq 1$)$

Hence, $\mathrm{CoF}_{3}$ should be handled in dry conditions to prevent decomposition.[6]

The preparation of battery electrodes which are composite of electroactive material, carbon and a polymeric matrix comprises several steps.[9] The mixing of electroactive material, carbon with polyvinylidene fluoride (PVDF) binder is usually performed with N-Methyl-2-pyrrolidone (NMP) solvent. The slurry is then casted onto a current collector. The solvent is evaporated at low temperature, i.e., $60-70{ }^{\circ} \mathrm{C}$ below the flash point $\left(96{ }^{\circ} \mathrm{C}\right)$ of NMP. To remove traces of humidity, a final heat treatment is usually performed at a temperature of around $105{ }^{\circ} \mathrm{C}$. All these steps can alter the structure/composition of the electroactive material. Here, we investigated the impact of these steps on the structure/composition of $\mathrm{CoF}_{3}$ electrode by means of high-energy total scattering data. We showed that the presence of carbon and binder enables to limit 
the decomposition of $\mathrm{CoF}_{3}$. By structural analysis of the electrode, we discovered a new phase, intermediate between $\mathrm{CoF}_{3}$ and $\mathrm{CoF}_{2}$, whose structure was solved using a rhombohedral cell isostructural to the corundum type structure with Co vacancies. This work points to the necessity to careful handling when dealing with certain metal fluorides.

\section{Results and Discussion}

To investigate the decomposition mechanism of $\mathrm{CoF}_{3}$ during electrode processing, we considered three types of samples that are the pristine $\mathrm{CoF}_{3}$ (handled in a dry glove box), $\mathrm{CoF}_{3}$ treated at $70{ }^{\circ} \mathrm{C}$ under air to mimic the solvent removal step and the electrode. It should be noted that the preparation of the electrode was performed using hand-milling which does not impact the crystal structure of the material. High intensity synchrotron based $\mathrm{x}$-ray $(\lambda=0.2128 \AA)$ scattering measurements was performed at the Advanced Photon Source. For convenience, the data were re-scaled in two-theta at the wavelength of copper $\lambda_{\mathrm{Cu}}=1.54 \AA$ (Figure 1). The X-ray diffraction pattern of the pristine $\mathrm{CoF}_{3}$ can be indexed using a rhombohedral R-3c cell.[10] We also noted a small amount of $\mathrm{CoF}_{2}$ impurity.[11] After a thermal treatment at $70{ }^{\circ} \mathrm{C}$ under ambient atmosphere, $\mathrm{CoF}_{3}$ readilly converts to $\mathrm{CoF}_{2}$. The electrode XRD pattern, however, differs from both $\mathrm{CoF}_{3}$ and $\mathrm{CoF}_{2}$ and could not be indexed using crystallographic database.[12] Moreover, the Bragg peaks showed broad lines that complexify the structural determination by conventional Rietveld analysis. 


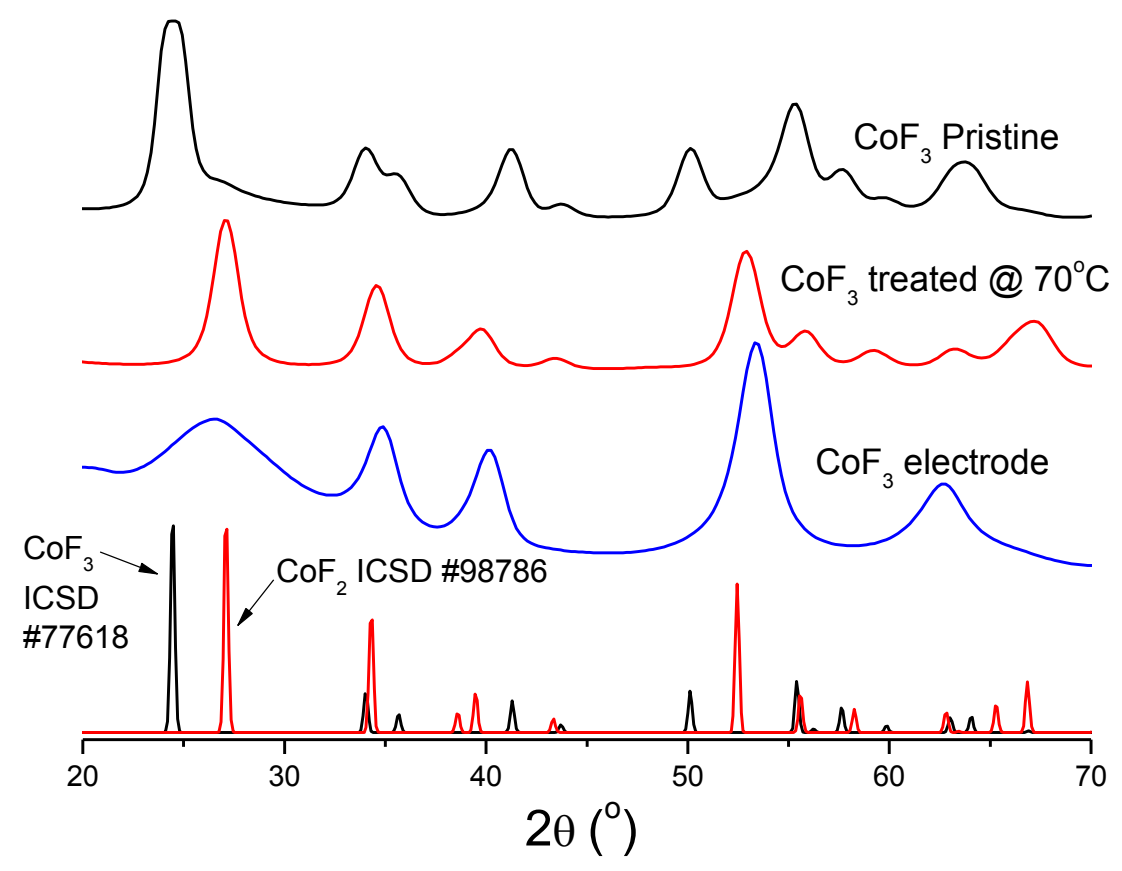

Figure 1. High-energy $\mathrm{X}$-ray diffraction patterns of pristine $\mathrm{CoF}_{3}$ (black), $\mathrm{CoF}_{3}$ treated at $70^{\circ} \mathrm{C}$ under ambient atmosphere (red) and electrode (blue). Reference XRD patterns of $\mathrm{CoF}_{2}$ and $\mathrm{CoF}_{3}$.

To better understand the composition and structural changes associated with the decomposition process of $\mathrm{CoF}_{3}$, we used the pair distribution function (PDF), G(r), which was obtained by Fourier transformed high-energy X-ray total scattering data. By providing real-space structural representation, PDF enables to obtain detailed information at the local to long-range order particularly suited to study disordered/nanostructured/amorphous compounds.[13] PDFs of the pristine $\mathrm{CoF}_{3}, \mathrm{CoF}_{2}$ $\left(\mathrm{CoF}_{3}\right.$ treated at $70^{\circ} \mathrm{C}$ under ambient atmosphere) and the electrode are gathered in Figure 2 with selected $r$-region characteristic of short-range, i.e., $1 \leq r \leq 6 \AA$, and intermediate/long-range orders, i.e., $r>4 \AA$. PDF represents a histogram of all atomatom distances within the sample. The first peak located at around $2 \AA$ corresponds to Co-F bonds. The position of the Co-F pair can be obtained by Gaussian fitting of the 
first peak yielding $2.04 \AA$ for $\mathrm{CoF}_{2}$ and $1.94 \AA$ for $\mathrm{CoF}_{3}$. In the electrode, the first peak is centered at $2.03 \AA$ which is close to that found in $\mathrm{CoF}_{2}$ and is therefore related to Co ${ }^{\mathrm{II}}$-F distances indicating that $\mathrm{CoF}_{3}$ was reduced during the electrode fabrication. The second peak at around 3.1 $\AA$ is close to Co-Co pairs found in the rutile $\mathrm{CoF}_{2}$ and arises from edge-shared $\mathrm{CoF}_{6}$ octahedra (label A, $\mathrm{d}_{\mathrm{Co}-\mathrm{Co}}=3.17 \AA$ ). This peak is absent in $\mathrm{CoF}_{3}$ which features only corner-shared $\mathrm{CoF}_{6}$ octahedra with $\mathrm{d}_{\mathrm{Co}-\mathrm{Co}}=3.6-3.7 \AA$ (label B). Note that the rutile phase presents both edge- and corner-shared $\mathrm{CoF}_{6}$ octahedra as revealed by the presence of the two sets of distances. At $r>4 \AA$, the PDF features of the electrode differ from those found in $\mathrm{CoF}_{2}$ and $\mathrm{CoF}_{3}$ indicating a different structural arrangement in agreement with XRD data. 

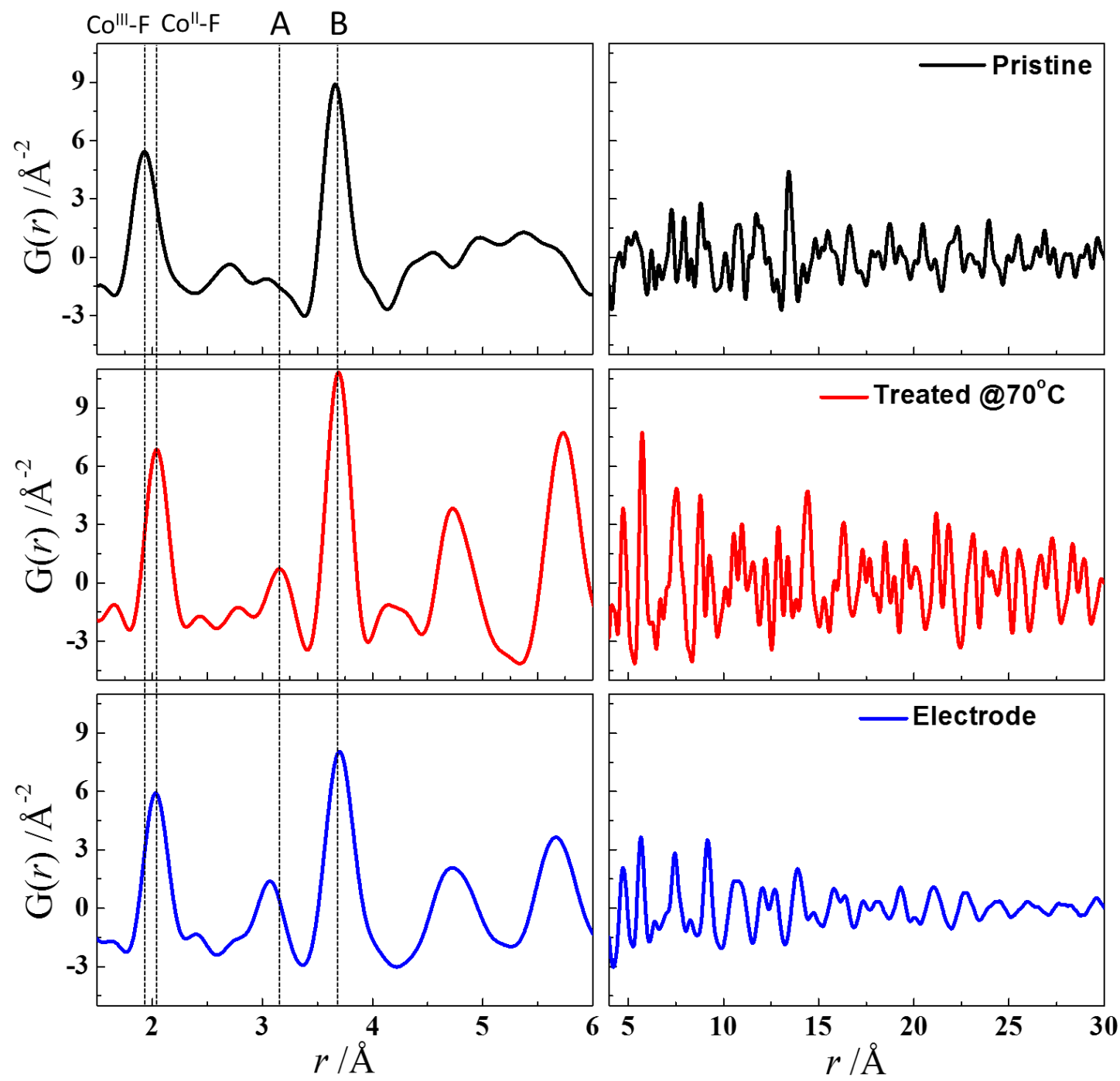

Figure 2. PDF profiles of pristine $\mathrm{CoF}_{3}$ (black), $\mathrm{CoF}_{2}\left(\mathrm{CoF}_{3}\right.$ treated at $70^{\circ} \mathrm{C}$ under atmosphere) (red) and electrode. A and B refer to Co-Co interatomic distances in edgeand corner-shared $\mathrm{CoF}_{6}$ octahedra, respectively.

To identify the structure stabilized during the electrode fabrication, we attempted to fit the PDF data using a real-space refinement.[14] First, we refined the PDF of pristine $\mathrm{CoF}_{3}$ and $\mathrm{CoF}_{2}$ (obtained by $\mathrm{CoF}_{3}$ treated at $@ 70{ }^{\circ} \mathrm{C}$ ) starting from previously reported structures.[10,11] Figure 3 presents the refined PDFs with reliability factors $R_{w}$ that attest the goodness of the fits. Following X-ray diffraction data, the PDF of the pristine 
$\mathrm{CoF}_{3}$ was refined using two-phase models based on $\mathrm{CoF}_{3}$ (space group $\mathrm{R}-3 \mathrm{c}$ ) and $\mathrm{CoF}_{2}$ (space group $\mathrm{P} 4 / 2 \mathrm{mnm}$ ). The amount of $\mathrm{CoF}_{2}$ and $\mathrm{CoF}_{3}$ within the pristine was 25 and 75at\%, respectively. Selected structural parameters extracted from the refinement are gathered in Table $\mathbf{1}$ and are in good agreement with previously reported structures.[10,11]

To fit the PDF of the electrode, we used different structural models particularly structures that shared common structural features. Notably, it is known that the corundum and rutile are structurally related.[15] According to the X-ray diffraction pattern in Figure 2, the rutile $\mathrm{CoF}_{2}$ phase seems to be present with a broad Bragg peak at around 26-27 $2 \theta\left(^{\circ}\right)$ which can be indexed with the (110) line of the tetragonal cell. Hence, we included it in the fit. Finally, the best fit (Figure 3) was obtained using a corundum-type phase $\mathrm{Co}_{2} \mathrm{~F}_{3}$. Moreover, the determination of the PDF scattering domain (sp parameter in the PDFGui software) yielded $8 \mathrm{~nm}$ which explained the broadness of the Bragg peaks. Table 2 gathered the structural parameters of the corundum phase obtained from the PDF refinement. The refinement of the Co (12c) rate occupancy indicates the presence of Co vacancies. Based on the general composition, the refined atomic occupancy yields $\mathrm{Co}_{1.26}{ }^{\mathrm{II}} \mathrm{Co}_{0.16}{ }^{\mathrm{III}} \square_{0.58} \mathrm{~F}_{3}$. 

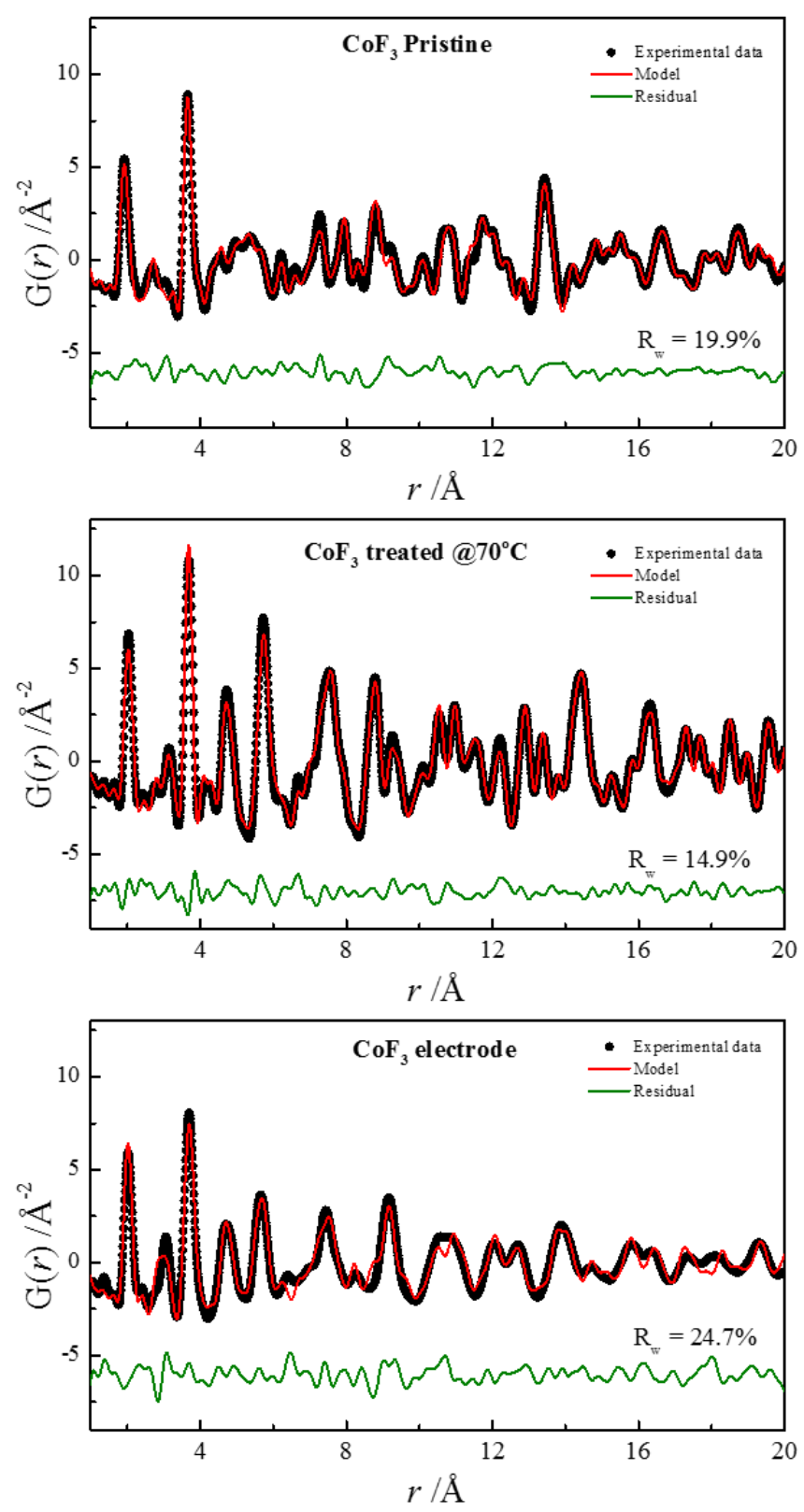

Figure 3. $\mathrm{PDF}$ refinements of pristine $\mathrm{CoF}_{3}, \mathrm{CoF}_{2}\left(\mathrm{CoF}_{3}\right.$ treated at $70^{\circ} \mathrm{C}$ under atmosphere) and $\mathrm{CoF}_{3}$ electrode.

Here, we showed that $\mathrm{CoF}_{3}$ decomposes to $\mathrm{CoF}_{2}$ via an intermediate phase derived from the corundum type structure. The structural representations of the three phases $\mathrm{CoF}_{2}$, $\mathrm{Co}_{1.26}{ }^{\mathrm{II}} \mathrm{Co}_{0.16}{ }^{\mathrm{III}} \square_{0.58} \mathrm{~F}_{3}$ and $\mathrm{CoF}_{3}$ are presented in Figure 4. Further works should be 
carried out to better understand the decomposition mechanism of $\mathrm{CoF}_{3}$ along with phase transformation path from $\mathrm{ReO}_{3}$, corundum to rutile type structures.
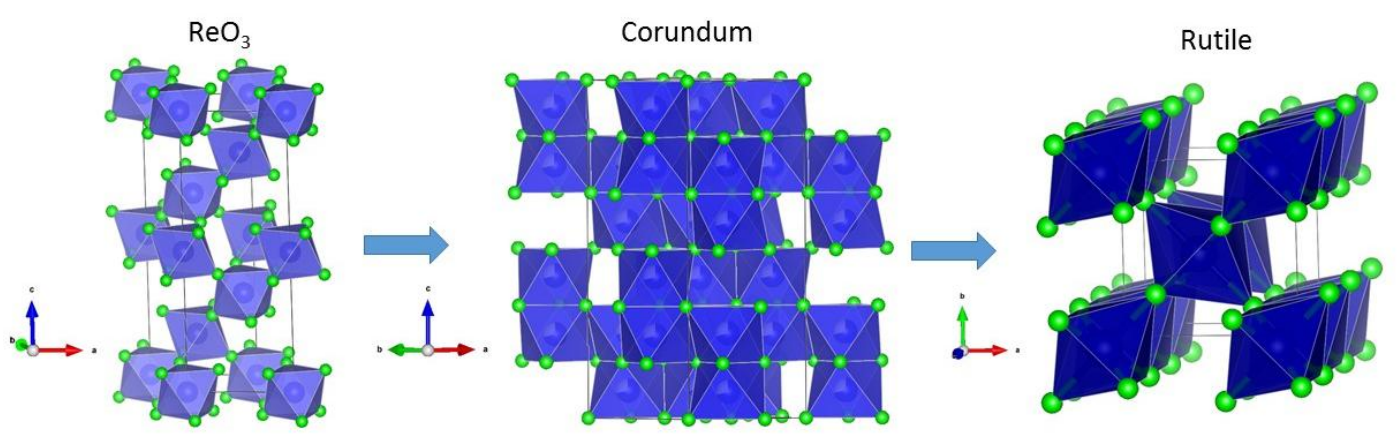

Figure 4. Structural representations of $\mathrm{ReO}_{3}\left(\mathrm{CoF}_{3}\right)$, corundum $\left(\mathrm{Co}_{1.26}{ }^{\mathrm{II}} \mathrm{Co}_{0.16}{ }^{\mathrm{III}} \square_{0.58} \mathrm{~F}_{3}\right)$ and rutile $\left(\mathrm{CoF}_{2}\right)$ type structures.

The as prepared electrode was cycled in glavanostatic mode versus metallic lithium. Figure 5 shows the galvanostatic curves obtained under $50 \mathrm{~mA} \cdot \mathrm{g}^{-1}$ with LP30 as the electrolyte. The theoretical capacity of $\mathrm{Co}_{1.26}{ }^{\mathrm{II}} \mathrm{Co}_{0.16}{ }^{\mathrm{III}} \square_{0.58} \mathrm{~F}_{3}$ is $572 \mathrm{mAh} \cdot \mathrm{g}^{-1}$. Upon discharge, a pseudo plateau region was observed at an average potential of $1.65 \mathrm{~V}$ yielding a capacity around $550 \mathrm{mAh} \cdot \mathrm{g}^{-1}$ which is close to the theoretical capacity. Moreover, the average potential is $350 \mathrm{mV}$ higher than the one display by $\mathrm{CoF}_{2}$ showing a slight variation of the insertion voltage between the two structures. The full discharge yielded around $1230 \mathrm{mAh} . \mathrm{g}^{-1}$ which can be assigned to the electrolyte decomposition. After the first charge, the capacity decreased to $505 \mathrm{mAh} \cdot \mathrm{g}^{-1}$ which suggest that the conversion reaction is almost reversible. Finally, after the second cycle, the capacity further decreased to $410 \mathrm{mAh} \cdot \mathrm{g}^{-1}$ which might be due to the inability to reach the trivalent state of cobalt in a reversible manner.[6] 


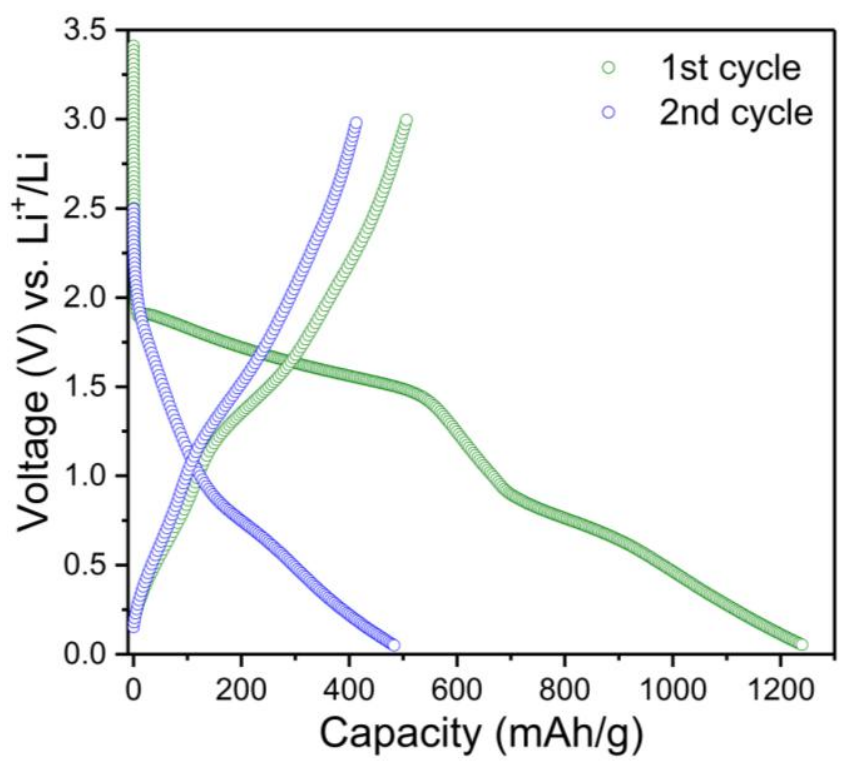

Figure 5. Galvanostatic discharge/charge curves of $\mathrm{Co}_{1.26}{ }^{\mathrm{II}} \mathrm{Co}_{0.16}{ }^{\mathrm{III}} \square_{0.58} \mathrm{~F}_{3}$ electrode cycled under $50 \mathrm{~mA} \cdot \mathrm{g}^{-1} \mathrm{vs}$. metallic lithium.

\section{Conclusion}

In this work, we reported on the structural analysis of an electrode made of $\mathrm{CoF}_{3}$. Based on high-energy $\mathrm{X}$-ray data, we showed that $\mathrm{CoF}_{3}$ decomposes during the electrode processing into a new structure/composition. Using the pair distribution function, we discovered that this structure corresponds to a defective corundum phase featuring Co vacancies, i.e., $\mathrm{Co}_{1.26}{ }^{\mathrm{II}} \mathrm{Co}_{0.16}{ }^{\mathrm{III}} \square_{0.58} \mathrm{~F}_{3}$. Hence, the decomposition of $\mathrm{CoF}_{3}\left(\mathrm{ReO}_{3}\right)$ toward $\mathrm{CoF}_{2}$ occurred via the corundum structure. 


\section{Experimental}

\subsection{Materials preparation and electrochemical measurements}

Thermal treatment of $\mathrm{CoF}_{3}$ pristine powder was conducted at $70{ }^{\circ} \mathrm{C}$ under air atmosphere for 7 hours.

$\mathrm{CoF}_{3}$ electrode was prepared by hand-milling of active material (80 wt $\%$ ), acetylene black (10 wt $\%)$ as conductive agent and polyvinylidene difluoride (10 wt $\%)$ previously dissolved in N-methyl-2-pyrrolidone (NMP, Sigma-Aldrich) as the binder. The resulting paste was coated onto a copper foil using a doctor blade. The electrode was dried in an oven under primary vacuum at $75{ }^{\circ} \mathrm{C}$ overnight to evaporate NMP solvent.

Electrochemical measurements were carried out using CR2032-type coin cells. The electrolyte was $1 \mathrm{M} \mathrm{LiPF}_{6}$ dissolved in a mixture of ethylene carbonate (EC) and dimethyl carbonate (DMC) $(1: 1, \mathrm{v} / \mathrm{v})$. The cells were assembled and tested with lithium metal as the anode and the reference electrode in the voltage range of 3.0-0.05 V vs. $\mathrm{Li}^{+} / \mathrm{Li}$ under $50 \mathrm{~mA} \cdot \mathrm{g}^{-1}$.

\subsection{Synchrotron diffraction}

Samples were loaded inside Kapton capillaries. Data were collected at the 11-ID-B beamline at the Advanced Photon Source at Argonne National Laboratory, using high energy X-rays $(\lambda=0.2128 \AA)$ allowing access to high values of momentum transfer $\mathrm{Q}_{\max } \approx 22 \AA .[16,17]$ The diffraction images were integrated within fit2D to obtain the one-dimensional diffraction data.[18] The G(r) function was extracted from the data 
using PDFgetX2,[19] after correcting for background and Compton scattering. The refinement of the PDF data was carried out using the PDFgui software.[20]

Structural representation was obtained by using VESPA program.[21]

\section{Acknowledgements}

We thank A. Demourgues for providing $\mathrm{CoF}_{3}$ sample. The work done at the Advanced Photon Source, an Office of Science User Facility operated for the U.S. Department of Energy (DOE) Office of Science by Argonne National Laboratory, was supported by the U.S. DOE under Contract DE-AC02-06CH11357. H.G., and D.D. wish to thank the French Fluorine Network for continuous support.

\section{References}

[1] P. Poizot, S. Laruelle, S. Grugeon, L. Dupont, J.-M. Tarascon, Nano-sized transition-metal oxides as negative-electrode materials for lithium-ion batteries, Nature. 407 (2000) 496-499. doi:10.1038/35035045.

[2] J. Cabana, L. Monconduit, D. Larcher, M.R. Palacín, Beyond Intercalation-Based Li-Ion Batteries: The State of the Art and Challenges of Electrode Materials Reacting Through Conversion Reactions, Adv. Mater. 22 (2010) E170-E192. doi:10.1002/adma.201000717.

[3] H. Arai, S. Okada, Y. Sakurai, J. Yamaki, Cathode performance and voltage estimation of metal trihalides, Journal of Power Sources. 68 (1997) 716-719. doi:10.1016/S0378-7753(96)02580-3.

[4] F. Badway, F. Cosandey, N. Pereira, G.G. Amatucci, Carbon Metal Fluoride Nanocomposites High-Capacity Reversible Metal Fluoride Conversion Materials as Rechargeable Positive Electrodes for Li Batteries, J. Electrochem. Soc. 150 (2003) A1318-A1327. doi:10.1149/1.1602454.

[5] H. Li, P. Balaya, J. Maier, Li-Storage via Heterogeneous Reaction in Selected Binary Metal Fluorides and Oxides, J. Electrochem. Soc. 151 (2004) A1878A1885. doi:10.1149/1.1801451.

[6] H. Groult, S. Neveu, S. Leclerc, A.-G. Porras-Gutierrez, C.M. Julien, A. Tressaud, E. Durand, N. Penin, C. Labrugere, Nano-CoF3 prepared by direct fluorination with F2 gas: Application as electrode material in Li-ion battery, Journal of Fluorine Chemistry. 196 (2017) 117-127. doi:10.1016/j.jfluchem.2016.10.003. 
[7] N. Louvain, J. Peyroux, M. Dubois, W. Simond, F. Leroux, Efficient Fluorinating Agent through Topochemical Fluorination of Co-Fe Layered Double Hydroxides, Inorg. Chem. 53 (2014) 852-860. doi:10.1021/ic402193x.

[8] J.V. Rau, V.R. Albertini, N.S. Chilingarov, S. Colonna, M. di Michiel, Observation of a New Co-F Compound Detected by Very-High-Energy X-ray Diffraction During Thermal Decomposition of $\mathrm{CoF}<\mathrm{SUB}>3</ \mathrm{SUB}\rangle$, Chemistry Letters. 31 (2002) 664-665. doi:10.1246/cl.2002.664.

[9] E. Talaie, P. Bonnick, X. Sun, Q. Pang, X. Liang, L.F. Nazar, Methods and Protocols for Electrochemical Energy Storage Materials Research, Chem. Mater. 29 (2017) 90-105. doi:10.1021/acs.chemmater.6b02726.

[10] A.L. Hector, E.G. Hope, W. Levason, M.T. Weller, The Mixed Valence Structure of "R-NiF3," Z. Anorg. Allg. Chem. 624 (1998) 1982-1988. doi:10.1002/(SICI)1521-3749(1998120)624:12<1982::AIDZAAC1982>3.0.CO;2-4.

[11] W. Jauch, M. Reehuis, A.J. Schultz, $\gamma$-ray and neutron diffraction studies of CoF2: magnetostriction, electron density and magnetic moments, Acta Cryst A. 60 (2004) 51-57. doi:10.1107/S0108767303022803.

[12] ICSD - Basic Search \& Retrieve, (n.d.). https://icsd.fizkarlsruhe.de/search/basic.xhtml (accessed July 27, 2017).

[13] S.J.L. Billinge, M.G. Kanatzidis, Beyond crystallography: the study of disorder, nanocrystallinity and crystallographically challenged materials with pair distribution functions, Chemical Communications. (2004) 749. doi:10.1039/b309577k.

[14] T. Egami, S.J.L. Billinge, Underneath the Bragg Peaks: Structural Analysis of Complex Materials, Elsevier, 2003.

[15] H. Katzke, R. Schlögl, Mechanism of the morphotropic transformation between the rutile and corundum structural types, Acta Cryst B, Acta Cryst Sect B. 59 (2003) 456-462. doi:10.1107/S0108768103010851.

[16] P.J. Chupas, X. Qiu, J.C. Hanson, P.L. Lee, C.P. Grey, S.J.L. Billinge, Rapidacquisition pair distribution function (RA-PDF) analysis, J Appl Crystallogr. 36 (2003) 1342-1347. doi:10.1107/S0021889803017564.

[17] P.J. Chupas, K.W. Chapman, P.L. Lee, Applications of an amorphous siliconbased area detector for high-resolution, high-sensitivity and fast time-resolved pair distribution function measurements, J Appl Crystallogr. 40 (2007) 463-470. doi:10.1107/S0021889807007856.

[18] A.P. Hammersley, S.O. Svensson, M. Hanfland, A.N. Fitch, D. Hausermann, Twodimensional detector software: From real detector to idealised image or two-theta scan, High Pressure Research. 14 (1996) 235-248. doi:10.1080/08957959608201408.

[19] X. Qiu, J.W. Thompson, S.J.L. Billinge, PDFgetX2: a GUI-driven program to obtain the pair distribution function from X-ray powder diffraction data, J Appl Crystallogr. 37 (2004) 678-678. doi:10.1107/S0021889804011744.

[20] C.L. Farrow, P. Juhas, J.W. Liu, D. Bryndin, E.S. Božin, J. Bloch, T. Proffen, S.J.L. Billinge, PDFfit2 and PDFgui: computer programs for studying nanostructure in crystals, J. Phys.: Condens. Matter. 19 (2007) 335219. doi:10.1088/0953-8984/19/33/335219. 
[21] K. Momma, F. Izumi, VESTA 3 for three-dimensional visualization of crystal, volumetric and morphology data, J Appl Crystallogr. 44 (2011) 1272-1276. doi:10.1107/S0021889811038970. 


\section{Figure Captions}

Figure 1. High-energy X-ray diffraction patterns of pristine $\mathrm{CoF}_{3}$ (black), $\mathrm{CoF}_{3}$ treated at $70^{\circ} \mathrm{C}$ under ambient atmosphere (red) and electrode (blue). Reference XRD patterns of $\mathrm{CoF}_{2}$ and $\mathrm{CoF}_{3}$.

Figure 2. PDF profiles of pristine $\mathrm{CoF}_{3}$ (black), $\mathrm{CoF}_{2}\left(\mathrm{CoF}_{3}\right.$ treated at $70^{\circ} \mathrm{C}$ under atmosphere) (red) and electrode. A and B refer to Co-Co interatomic distances in edgeand corner-shared $\mathrm{CoF}_{6}$ octahedra, respectively.

Figure 3. PDF refinements of pristine $\mathrm{CoF}_{3}, \mathrm{CoF}_{2}\left(\mathrm{CoF}_{3}\right.$ treated at $70^{\circ} \mathrm{C}$ under atmosphere) and $\mathrm{CoF}_{3}$ electrode.

Figure 4. Structural representations of $\mathrm{ReO}_{3}\left(\mathrm{CoF}_{3}\right)$, corundum $\left(\mathrm{Co}_{1.26}{ }^{\mathrm{II}} \mathrm{Co}_{0.16}{ }^{\mathrm{III}} \square_{0.58} \mathrm{~F}_{3}\right)$ and rutile $\left(\mathrm{CoF}_{2}\right)$ type structures.

Figure 5. Galvanostatic discharge/charge curves of $\mathrm{Co}_{1.26}{ }^{\mathrm{II}} \mathrm{Co}_{0.16}{ }^{\mathrm{III}} \square_{0.58} \mathrm{~F}_{3}$ electrode cycled under $50 \mathrm{~mA} \cdot \mathrm{g}^{-1} \mathrm{vs}$. metallic lithium. 
Table 1

Structural parameters extracted from the PDF refinement of pristine $\mathrm{CoF}_{3}$ :

\begin{tabular}{lll}
\hline Parameters & $\mathrm{CoF}_{3}$ & $\mathrm{CoF}_{2}$ \\
\hline Space group & $\mathrm{R}-3 \mathrm{c}$ & $\mathrm{P} 42 / \mathrm{mnm}$ \\
$a(\AA)$ & $5.031(2)$ & $4.63(1)$ \\
$c(\AA)$ & $13.244(8)$ & $3.17(2)$ \\
Atom $($ Wyckoff site $)$ & $\mathrm{F}(18 \mathrm{e})$ & $\mathrm{F}(4 \mathrm{f})$ \\
Atomic coordinates $(\mathrm{x}, \mathrm{y}, \mathrm{z})$ & $(0,0.25,0.616(2))$ & $(0.311(7), 0.311(7), 0)$ \\
Size parameter $(\AA)$ & $\mathrm{N} . \mathrm{A}$ & $20(2)$ \\
Molar \% & $69 \%$ & $31 \%$ \\
\hline
\end{tabular}

Table 2

Structural parameters extracted from the PDF refinement of the electrode:

\begin{tabular}{lc}
\hline Parameters & $\mathrm{Co}_{1.26}{ }^{\mathrm{II}} \mathrm{Co}_{0.16}{ }^{\mathrm{III}} \square_{0.58} \mathrm{~F}_{3}$ \\
\hline Space group & $\mathrm{R}-3 \mathrm{c}(167)$ \\
$a(\AA)$ & $5.157(3)$ \\
$c(\AA)$ & $13.78(1)$ \\
& $\mathrm{Co}(12 \mathrm{c})$ \\
Atom (Wyckoff site) & $(0,0,0.3371(5) / 0.71(2)$ \\
Atomic coordinates $(\mathrm{x}, \mathrm{y}, \mathrm{z}) /$ occupancy & $\mathrm{F}(18 \mathrm{e})$ \\
& $(0.305(1), 0,0.25) / 1.01(3)$ \\
\hline
\end{tabular}

